\title{
Application of cDNA Macroarray for Simultaneous Detection of 12 Potato Viruses
}

\author{
T. Maoka, Potato Production and Protection Research Team, National Agricultural Research Center for Hokkaido \\ Region, 1 Hitsujigaoka, Toyohira-ku, Sapporo, Hokkaido, 062-8555 Japan; S. Sugiyama and Y. Maruta, LAB \\ Company, Ltd. 2-12 N27W6 Kita-ku Sapporo, Hokkaido, 001-0027 Japan; and T. Hataya, Laboratory of Pathogen- \\ Plant Interactions, Plant Breeding Science, Division of Applied Bioscience, Research Faculty of Agriculture, Hok- \\ kaido University, Kita 9, Nishi 9, Kita-ku, Sapporo, 060-8589 Japan
}

\begin{abstract}
Maoka, T., Sugiyama, S., Maruta, Y., and Hataya, T. 2010. Application of cDNA macroarray for simultaneous detection of 12 potato viruses. Plant Dis. 94:1248-1254.

A complementary DNA (cDNA) macroarray was developed for simultaneous detection of 12 different potato viruses. A suitable region in the viral genome for each was selected for Alfalfa mosaic virus, Cucumber mosaic virus, Potato aucuba mosaic virus, Potato leafroll virus, Potato mop-top virus, Potato virus A, Potato virus $M$, Potato virus $S$, Potato virus $X$, Potato virus $Y$, Tomato ringspot virus, and Tomato spotted wilt virus, and their respective cDNAs were cloned into plasmid vectors. Capture probes for each virus ranging from 290 to $577 \mathrm{bp}$ were generated by polymerase chain reaction (PCR) and immobilized on a nylon membrane. Total RNAs were extracted from each of these virus infected-plants, and cDNAs were synthesized from the RNA extracts using a random 9-mer primer. Subsequently, PCR reactions were performed using one primer pair for each of the 12 viruses. During PCR, amplified cDNAs were labeled with biotin and used as a target for hybridization analyses on a macroarray membrane. Hybridization signals between capture probes for the 12 viruses and their respective target cDNAs were observed using chemiluminescent or colorimetric detection. In all viruses, hybridization signals with capture probes were detected only when homologous virus targets were examined, and no hybridization to healthy plant extract was observed, facilitating identification of each virus. The results by colorimetric detection agreed with those obtained using chemiluminescence. The macroarray method developed was $5 \times 10^{2}$ to $4 \times 10^{6}$ times more sensitive than enzyme-linked immunosorbent assay and 5 to $5 \times 10^{4}$ times more sensitive than reverse-transcription PCR, except for $\mathrm{Al}$ falfa mosaic virus. Colorimetric detection and substantial reduction in cross-hybridization signals much improved the method compared with other array-based detection methods for practical use.
\end{abstract}

Thirty-six distinct viruses and a viroid have been reported as causal agents of potato (Solanum tuberosum) diseases around the world $(29,32)$ (Potato yellow mosaic virus is excluded because it is synonymous with Tomato yellow mosaic virus.). In Japan, 12 viruses-Alfalfa mosaic virus (AMV), Cucumber mosaic virus (CMV), Potato aucuba mosaic virus (PAMV), Potato leafroll virus (PLRV), Potato mop-top virus (PMTV), Potato virus A (PVA), Potato virus $M$ (PVM), Potato virus $S$ (PVS), Potato virus $X$ (PVX), Potato virus Y (PVY), Tomato ringspot virus (ToRSV), and Tomato spotted wilt virus (TSWV)- have been identified as causal agents of virus diseases of potato $(3,5,15-19,24-26,29,35)$. These pathogens are transmitted in seed tubers from generation to generation and cause severe reduction in yield and quality. Con-

Corresponding author: T. Maoka

E-mail: maokat@affrc.go.jp

Accepted for publication 28 June 2010.

(C) 2010 The American Phytopathological Society
doi:10.1094/PDIS-12-09-0787 trol strategies depend on the production of virus-free mother plants through tissue culture and the exclusion of infected seed potato tubers during plant quarantine and seed certification. Virus-detection methods are important factors for maintaining an economically viable certification program.
Molecularly based detection methods such as reverse-transcription polymerase chain reaction (RT-PCR) were established for some of the above viruses $(13,26$, 27,31). However, PCR conditions varied by target virus, and no method was available to detect the 12 viruses simultaneously. Recently, macroarrays have been developed to detect 11 potato viruses and a viroid $(1,2)$. These viruses were detected by hybridization using synthesized oligonucleotide probes on membranes and chemically labeled targets prepared by the random primed amplified procedure. However, this macroarray was not completely satisfactory; there was cross-hybridization between viruses, making interpretation difficult (2). In addition, they required expensive tools such as an imaging system for chemiluminescence, preventing ubiquitous distribution of this technique. In order to solve these problems, we developed a simultaneous detection method for the 12 potato viruses using a complementary DNA (cDNA) macroarray. To enhance sensitivity and reduce cross-hybridization, virus-specific capture probes and biotinlabeled target amplification were used. In addition, a colorimetric detection method was employed for convenient use. The sensitivity of the method was compared with currently available diagnostic methods (i.e., enzyme-linked immunosorbent assay [ELISA] and RT-PCR) and the effi-
Table 1. Isolates of potato viruses used

\begin{tabular}{lllc}
\hline Virus $^{\text {a }}$ & Isolate & Propagation host & References or origin \\
\hline AMV & No. 14 & Nicotiana benthamiana & This report \\
CMV & IC & N. benthamiana & 30 \\
PAMV & Hokudai & N. occidentalis & This report \\
PLRV & No. 264 & Solanum tuberosum & This report \\
PMTV & Hiroshima & N. benthamiana & 17 \\
PVA & MAFF307028c & N. benthamiana & 24 \\
PVM & 17-2 & N. occidentalis & This report \\
PVS & M & N. occidentalis & This report \\
PVX & O-IC249 & $N$. benthamiana & This report \\
PVY & Y28 & $N$. benthamiana & This report \\
ToRSV & MQ & $N$. benthamiana & 29 \\
TSWV & pt1 & $N$. benthamiana & 26 \\
\hline
\end{tabular}

a AMV = Alfalfa mosaic virus, CMV = Cucumber mosaic virus, $\mathrm{PAMV}=$ Potato aucuba mosaic virus, $\mathrm{PLRV}=$ Potato leafroll virus, $\mathrm{PMTV}=$ Potato mop-top virus, $\mathrm{PVA}=$ Potato virus $A, \mathrm{PVM}=$ Potato virus $M, \mathrm{PVS}=$ Potato virus $S, \mathrm{PVX}=$ Potato virus $X, \mathrm{PVY}=$ Potato virus $Y$, ToRSV $=$ Tomato ringspot virus, TSWV = Tomato spotted wilt virus.

b Subgroup I.

${ }^{c}$ MAFF $=$ from collection by the Genebank Project of the National Institute of Agrobiological Sciences (NIAS), Japan.

d Strain $\mathrm{O}$. 
cacy of the method was investigated using field samples.

\section{MATERIALS AND METHODS}

Virus and RNA extraction. All the viruses used in this study were obtained from potato plants in Japan (Table 1). Isolate IC of CMV belongs to subgroup I (30). PVY isolate Y28 belongs to the $\mathrm{PVY}^{\mathrm{O}}$ strain. PLRV, PVX, and PVY were kindly provided by Mr. H. Fuwa, National Centre for Seeds and Seedlings, Japan, and TSWV by Dr. K. Matsuo, Nagasaki Agriculture and Forestry Experiment Station, Japan. These viruses were propagated in suitable hosts (Table 1) and stored at $-80^{\circ} \mathrm{C}$ until use. Total RNA was extracted from $50 \mathrm{mg}$ of frozen leaf tissue using TRIzol reagent (Invitrogen, Carlsbad, CA), dissolved in $50 \mu \mathrm{l}$ of nuclease-free water (Promega Corp., Madison, WI), and stored at $-80^{\circ} \mathrm{C}$ until use. Isolates of $\mathrm{PVY}^{\mathrm{N}}$ and PVM strains from our laboratory collection were used to test primers and probes.

Capture probes and cDNA array construction. Reference sequences used for primer design to amplify cDNA of viral RNA genome were obtained from the National Center for Biotechnology Information (NCBI) database (6). The genomic sequences of each virus were aligned using DNASIS software (Hitachi Software Engineering, Yokohama, Japan). Regions of sequence identity conserved among aligned sequences were identified visually and used to design primers. To avoid selfannealing and cross-hybridization, genespecific sequences that have no palindromes were selected using DNASIS (Hitachi Software Engineering) and BLAST (4) in NCBI, respectively. Primer sets that amplified fragments of approximately 300 to $600 \mathrm{bp}$ were selected (Table 2). For PLRV, PVS, PVX, and PVY, the primer sets designed by Sato et al. (31) were used.

Each capture probe was prepared by PCR from the corresponding viral cDNA cloned into the plasmid vectors as described below. PCR products were purified with QIAquick PCR Purification Kit (Qiagen, Hilden, Germany) and used for spotting as capture probes.

In all, $5 \mathrm{ng}$ of each capture probe in 0.2 $\mu \mathrm{l}$ of distilled water was spotted in quadruplicate onto Biodyne plus (Pall, Port Washington, NY) nylon membranes using the high-throughput liquid handling systems with glass syringes, following the method of Sugiyama et al. (34). Membranes were incubated at $120^{\circ} \mathrm{C}$ for $30 \mathrm{~min}$ in a hybridization oven (Asahi Techno Glass, Chiba, Japan) to denature the cDNA capture probes on the solid phase. Probes were immobilized by irradiation $\left(120 \mathrm{~mJ} / \mathrm{cm}^{2}\right)$ at $254 \mathrm{~nm}$ in a UV cross-linker (UVP, Upland, CA). In preliminary trials, blotting was made in a square on the membrane (65 by $25 \mathrm{~mm}$; Fig. 1). For practical use, blotting was made in a line in the membrane ( 85 by $27 \mathrm{~mm}$ ) and each virus name for the capture probe was printed below the quadruple spots, with the individual lot number on the left of the membrane (Fig. 2).

Cloning and sequence analysis. Each viral cDNA was cloned into pT7Blue T (Novagen, Madison, WI) or pGEM-T Easy (Promega Corp.) vectors as described previously (21). Cloned cDNAs were sequenced with the BigDye Terminator Cycle Sequencing Kit (Applied Biosystems, Foster City, CA) and 310 Genetic Analyzer (Applied Biosystems) according to the manufacturer's instructions. Alignment of the nucleotide sequence data was performed using DNASIS (Hitachi Software Engineering). Nucleotide sequence data are available in the DDBJ/EMBL/GenBank databases under the accession numbers AB451173 to AB451184 (Table 3).

RT, labeling RT-PCR, hybridization, and detection. For first-strand cDNA synthesis, $1 \mu \mathrm{l}$ of total RNA from plants was mixed with $1 \mu \mathrm{l}(100 \mathrm{U} / \mu \mathrm{l})$ of ReverTra Ace reverse transcriptase (TOYOBO, Osaka, Japan), $10 \mu$ l of nuclease-free water (Promega Corp.), $4 \mu \mathrm{l}$ of $5 \times$ RT buffer (TOYOBO), $1 \mu \mathrm{l}$ of $10 \mu \mathrm{M}$ random 9-mer primer (TaKaRa, Otsu, Japan), $2 \mu \mathrm{l}$ of 10 $\mathrm{mM}$ dNTPs, and $1 \mu \mathrm{l}(40 \mathrm{U} / \mu \mathrm{l})$ of a porcine liver ribonuclease inhibitor (TaKaRa). First-strand cDNA synthesis was carried out at $30^{\circ} \mathrm{C}$ for $10 \mathrm{~min}, 42^{\circ} \mathrm{C}$ for $20 \mathrm{~min}$, and $99^{\circ} \mathrm{C}$ for $5 \mathrm{~min}$.

For PCR amplification of cDNA, $2 \mu \mathrm{l}$ of first-strand cDNA was mixed with $2 \mu \mathrm{l}$ of 10× PCR Gold Buffer (Applied Biosystems), $1 \mu \mathrm{l}$ of $25 \mathrm{mM} \mathrm{MgCl}_{2}, 1 \mu \mathrm{l}$ of
dNTPs (4 mM each of dATP, dGTP, and $\mathrm{dCTP}$ and $2 \mathrm{mM}$ dTTP), $2 \mu \mathrm{l}$ of $1 \mathrm{mM}$ biotin-16-dUTP (Roche, Mannheim, Germany), $1 \mu \mathrm{l}$ each of $10 \mu \mathrm{M}$ forward and reverse primers (Table 2$), 0.125 \mu \mathrm{l}(5 \mathrm{U} / \mu \mathrm{l})$ of AmpliTaq Gold LD (Applied Biosystems), and $10.875 \mu \mathrm{l}$ of distilled water. The PCR program consisted of one cycle of $94^{\circ} \mathrm{C}$ for $9 \mathrm{~min} ; 30$ cycles of $94^{\circ} \mathrm{C}$ for 1 $\min , 55^{\circ} \mathrm{C}$ for $2 \mathrm{~min}$, and $72^{\circ} \mathrm{C}$ for $3 \mathrm{~min}$; and final extension at $72^{\circ} \mathrm{C}$ for $7 \mathrm{~min}$.

To prepare the labeled target cDNAs using first-strand cDNA synthesized from total RNA from each plant, 12 different PCR reactions each with one pair of primers were performed using the same primer sets used in capture probe amplification (Table 2). Two microliters each of biotinlabeled cDNA from each PCR reaction were mixed and purified by MinElute PCR Purification Kit (Qiagen, Germantown, MD). Eluted solution $(10 \mu \mathrm{l})$ was mixed with $90 \mu \mathrm{l}$ of distilled water, boiled for 5 min, and chilled rapidly on ice.

Before hybridization, membranes were preincubated in a plastic bag with $5 \mathrm{ml}$ of PerfectHyb hybridization solution (TOYOBO) at $70^{\circ} \mathrm{C}$ for $1 \mathrm{~h}$. The hybridization solution was discarded; then, hybridization was performed overnight in $5 \mathrm{ml}$ of PerfectHyb hybridization solution with $100 \mu \mathrm{l}$ of cDNA targets in a hybridization oven at $70^{\circ} \mathrm{C}$. The membrane was washed three times in wash buffer I containing $2 \times$ SSC $(1 \times \mathrm{SSC}$ is $0.15 \mathrm{M} \mathrm{NaCl}$ plus $0.015 \mathrm{M}$ sodium citrate; $\mathrm{pH} 7.0$ ) and $0.1 \%$ sodium dodecyl sulfate (SDS) at $70^{\circ} \mathrm{C}$ for $10 \mathrm{~min}$ and rinsed three times in wash buffer II

Table 2. Primer sequences used for reverse-transcription polymerase chain reaction and macroarray

\begin{tabular}{|c|c|c|c|}
\hline Virus $^{a}$ & Direction $^{b}$ & Primer designation & Sequence $\left(5^{\prime}\right.$ to $\left.3^{\prime}\right)$ \\
\hline \multirow[t]{2}{*}{ AMV } & $\mathrm{F}$ & AMV2F & CAAGAATTTCCTCATGGCGCGTTT \\
\hline & $\mathrm{R}$ & AMV1R & GGGTACATCAATGACGATCAAAGA \\
\hline \multirow[t]{2}{*}{ CMV } & $\mathrm{F}$ & CMV1F & AGAGAGTAGGTACAACGAAGGAGG \\
\hline & $\mathrm{R}$ & CMV1R & ACGTTCTCGAAGGCATCTCTGGAA \\
\hline \multirow[t]{2}{*}{ PAMV } & $\mathrm{F}$ & PAMV8P & ACCCAAGCGTTCCTATATACTC \\
\hline & $\mathrm{R}$ & PAMV8M & GATTGCTGGCAATGATTTGACC \\
\hline \multirow[t]{2}{*}{ PLRV } & $\mathrm{F}$ & PLRVCP9Pc & CGCTCAAGAAGAACTGGAG \\
\hline & $\mathrm{R}$ & PLRVCPE1M $\mathrm{M}^{\mathrm{c}}$ & CCGAATTCCTATTTGGGGTTTTGCAA \\
\hline \multirow[t]{2}{*}{ PMTV } & $\mathrm{F}$ & PMTV1F & TCGACGGCGAGCGTGTCACTATTC \\
\hline & $\mathrm{R}$ & PMTV4R & TCAAACACGCCTCAGCCAACTCCC \\
\hline \multirow[t]{2}{*}{ PVA } & $\mathrm{F}$ & PVA2F & GAGAATGGAACYTCTCCAGACATT \\
\hline & $\mathrm{R}$ & PVA3R & ATAGTACGGCACTTCGGTTACACC \\
\hline \multirow[t]{2}{*}{ PVM } & $\mathrm{F}$ & PVM22F & GGTTTCGCACACATTTGCCGCGTGA \\
\hline & $\mathrm{R}$ & PVM21R & TTCGAAGTTCCACAGTGCTTCCTCC \\
\hline \multirow[t]{2}{*}{ PVS } & $\mathrm{F}$ & PVS7Pc & TTCCCAACAGGCGCAGTG \\
\hline & $\mathrm{R}$ & PVS2Mc & CTAAACGGTCTGCCTTCAT \\
\hline \multirow[t]{2}{*}{ PVX } & $\mathrm{F}$ & PVX1Pc & TCCTTATTCCAACGGCATC \\
\hline & $\mathrm{R}$ & PVX1M ${ }^{c}$ & ATCTAGGCTGGCAAAGTCG \\
\hline \multirow[t]{2}{*}{ PVY } & $\mathrm{F}$ & PVYCP6Pc & GGTCCAAAATGAGAATGCC \\
\hline & $\mathrm{R}$ & PVYCP6M" & TCTTGTGTACTGATGCCAC \\
\hline \multirow[t]{2}{*}{ ToRSV } & $\mathrm{F}$ & ToR8F & CAACACCCTTTGTCTCTACTTATTTCA \\
\hline & $\mathrm{R}$ & ToR11R & СТААССТАAАACTCACCCCGCGTCC \\
\hline \multirow[t]{2}{*}{ TSWV } & $\mathrm{F}$ & TSWV13F & ATGTCTTCAAGTGTTTATGAGTCGATC \\
\hline & $\mathrm{R}$ & TSWV15R & AGTGCCAGAACAGAGTCATCAATATT \\
\hline
\end{tabular}

a $\mathrm{AMV}=$ Alfalfa mosaic virus, $\mathrm{CMV}=$ Cucumber mosaic virus, $\mathrm{PAMV}=$ Potato aucuba mosaic virus $\mathrm{PLRV}=$ Potato leafroll virus, $\mathrm{PMTV}=$ Potato mop-top virus, $\mathrm{PVA}=$ Potato virus $A, \mathrm{PVM}=$ Potato virus $M, \mathrm{PVS}=$ Potato virus $S, \mathrm{PVX}=$ Potato virus $X, \mathrm{PVY}=$ Potato virus $Y$, ToRSV $=$ Tomato ringspot virus, TSWV = Tomato spotted wilt virus.

${ }^{\mathrm{b}} \mathrm{F}=$ forward and $\mathrm{R}=$ reverse.

c Designed by Sato et al. (31). 
(0.1× SSC and $0.1 \%$ SDS) at $70^{\circ} \mathrm{C}$ for 5 min. Hybridized cDNA targets were detected using the Phototope-Star Detection Kit for Nucleic Acids (New England Biolabs, Ipswich, MA) as follows. The membrane was washed with $4.5 \mathrm{ml}$ of blocking buffer (5\% SDS, $125 \mathrm{mM} \mathrm{NaCl}, 25 \mathrm{mM}$ sodium phosphate, $\mathrm{pH}$ 7.2) at room temperature for $10 \mathrm{~min}$ and then in $15 \mathrm{ml}$ of blocking buffer containing $10 \mu$ of streptavidin for $7 \mathrm{~min}$. After washing three times with wash buffer III (1:10 dilution of blocking buffer) for $5 \mathrm{~min}$, the membrane was then incubated in $15 \mathrm{ml}$ of blocking buffer containing $10 \mu \mathrm{l}$ of biotinylated alkaline phosphatase for $7 \mathrm{~min}$. The membrane was washed three times with wash buffer III for $5 \mathrm{~min}$ and two times with wash buffer IV $(10 \mathrm{mM} \mathrm{NaCl}, 1 \mathrm{mM}$ $\mathrm{MgCl}_{2}, 10 \mathrm{mM}$ Tris-HCl, $\mathrm{pH}$ 9.5) for 5 min. The membrane was then incubated with the CDP-Star reagent for chemiluminescent detection. The image of each filter was obtained using the Fluor-S MultiImager system (Bio-Rad, Hercules, CA). Colorimetric detection was performed as follows: after washing with buffer IV, the membrane was incubated for $1 \mathrm{~h}$ in $10 \mathrm{ml}$ of staining buffer $\left(50 \mathrm{mM} \mathrm{MgSO}_{4}, 100\right.$ $\mathrm{mM}$ Tris buffer, $\mathrm{pH}$ 9.5) that contained 4 $\mathrm{mg}$ of nitroblue tetrazolium (NBT) and 1.9 $\mathrm{mg}$ of 5-bromo-4-chloro-3-indolyl phosphate (BCIP) (Roche), washed three times with distilled water, and dried in the dark. Signals were judged visually. A schematic outline of the procedure for macroarray detection of the 12 viruses for practical use is illustrated in Figure 3.

RT-PCR for agarose gel analysis. First-strand cDNA synthesis was carried
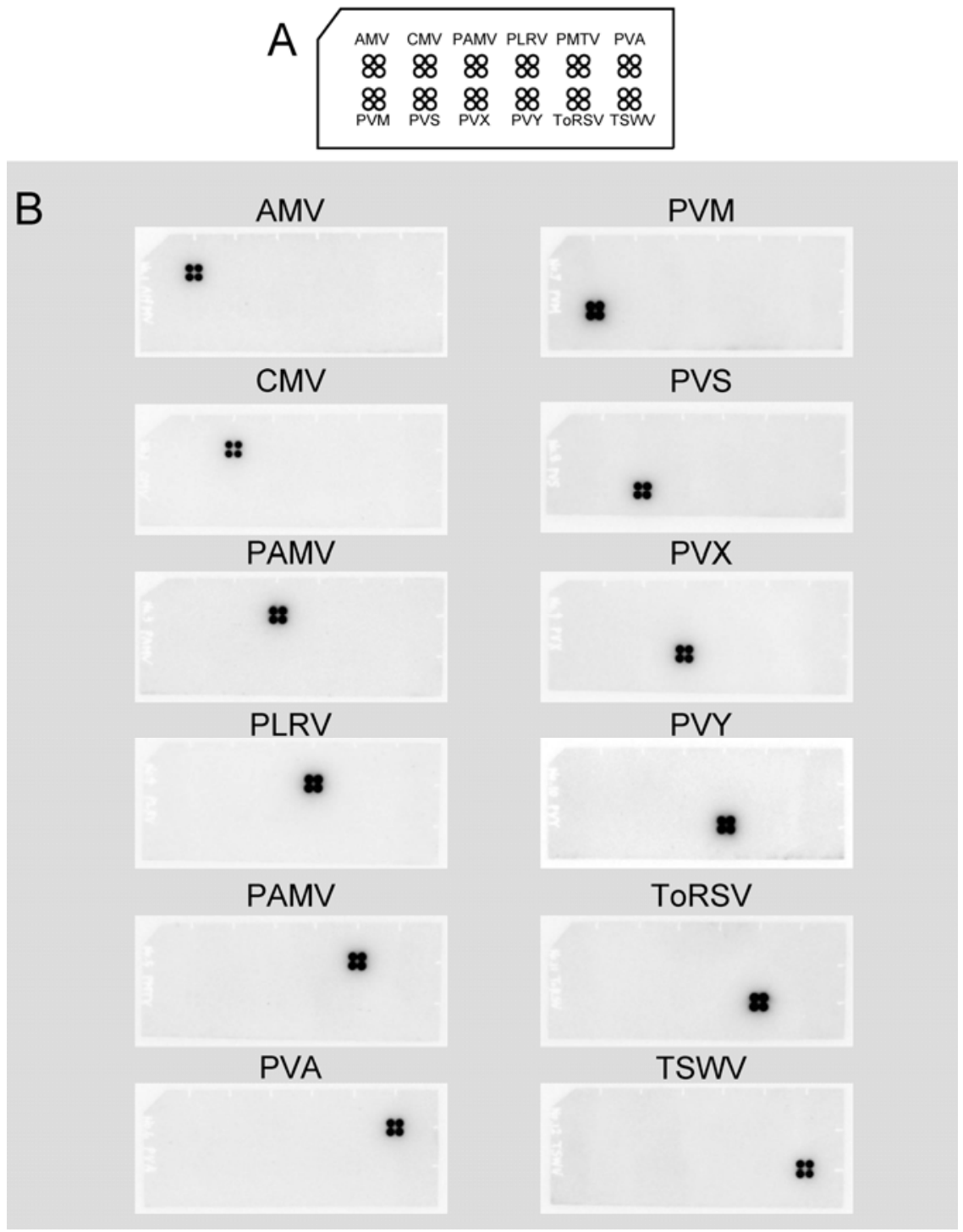

Fig. 1. Macroarray detection of 12 viruses from single infected samples. A, Diagram of the spotting pattern of complementary DNA probes. Names of viruses are indicated above or below each blotting position. $\mathrm{AMV}=$ Alfalfa mosaic virus, $\mathrm{CMV}=$ Cucumber mosaic virus, $\mathrm{PAMV}=$ Potato aucuba mosaic virus, $\mathrm{PLRV}=$ Potato leafroll virus, $\mathrm{PMTV}=$ Potato mop-top virus, $\mathrm{PVA}=$ Potato virus $\mathrm{A}, \mathrm{PVM}=$ Potato virus $M, \mathrm{PVS}=$ Potato virus $S, \mathrm{PVX}=$ Potato virus $X, \mathrm{PVY}=$ Potato virus $Y$, ToRSV $=$ Tomato ringspot virus, TSWV = Tomato spotted wilt virus. B, Virus detection from single infected samples. Specific signals on the membrane were detected using chemiluminescence. out as described above, with an exception as follows. Total RNA $(1 \mu \mathrm{l})$ was mixed with $0.03 \mu \mathrm{l}(35 \mathrm{U} / \mu \mathrm{l})$ of AMV reversetranscriptase XL (Life Sciences, St. Petersburg, FL), $6.37 \mu$ l of nuclease-free water (Promega Corp.), $1 \mu \mathrm{l}$ of $10 \times$ reaction buffer (Life Sciences), $1 \mu \mathrm{l}$ of $10 \mu \mathrm{M}$ reverse primer (Table 2), $0.5 \mu \mathrm{l}$ of $10 \mathrm{mM}$ dNTPs, and $0.1 \mu \mathrm{l}(40 \mathrm{U} / \mu \mathrm{l})$ of a porcine liver ribonuclease inhibitor (TaKaRa). PCR was conducted as described, with an exception that biotin-16-dUTP was not used. RT-PCR product $(5 \mu \mathrm{l})$ was separated on a $1 \%$ agarose gel in Tris-acetateEDTA buffer (40 mM Tris-acetate and 1 mM EDTA), stained in ethidium bromide solution, and photographed under UV illumination.

ELISA. Double-antibody sandwich (DAS)-ELISA essentially followed the method of Clark and Adams (9), using commercially available antibodies and enzyme-conjugated antibodies at recommended dilutions; PMTV antibody and enzyme-conjugated antibody were provided by Neogen (Scotland, UK) and others by Agdia (Elkhart, IN). Assays were carried out according to Agdia's instructions. Samples were considered as positive when absorbance at $405 \mathrm{~nm}$ was at least three times greater than the mean absorbance of healthy controls after incubation for 60 to $90 \mathrm{~min}$ at room temperature.

Comparison of ELISA, RT-PCR, and macroarray. Sensitivity in virus detection was compared between ELISA, RT-PCR, and macroarray based on dilution end point. Leaf mass that corresponded to each of the detection thresholds indicated as dilution end point was calculated as follows. For ELISA, $50 \mathrm{mg}$ of leaf samples frozen at $-80^{\circ} \mathrm{C}$ (Table 1) were ground (defined as $\times 1$ ). The original leaf extract (approximately $50 \mu \mathrm{l}$ ) was diluted with 200 $\mu \mathrm{l}$ of extraction buffer (Agdia) as $\times 5$ and further diluted with extraction buffer to obtain a fivefold dilution series. Dilutions of $5^{-3}$ through $5^{-12}$ were used, and each ELISA well received $100 \mu \mathrm{l}$ of diluted samples. A $100-\mu \mathrm{l}$ solution diluted to $5^{-3}$ to $5^{-12}$ in a well was estimated to include 800 to 0.0004 $\mu \mathrm{g}$ of infected leaf tissue, respectively.

For RT-PCR and macroarray, leaf samples were thoroughly homogenized and 50 $\mathrm{mg}$ of homogenates was used to extract total RNA in $50 \mu \mathrm{l}$ of nuclease-free water (Promega Corp.) as described above. The original RNA extract was designated as $\times 1$ and diluted with nuclease-free water (Promega Corp.) to obtain a fivefold dilution series from $5^{-3}$ through $5^{-14}$. For RTPCR and macroarray analyses, $1 \mu \mathrm{l}$ of total RNA dilution was used. We estimated that $1 \mu \mathrm{l}$ of the original total RNA derived from $1 \mathrm{mg}$ of leaf tissue and that samples diluted to $5^{-3}$ to $5^{-14}$ contained 8 to $0.0000002 \mu \mathrm{g}$ of leaf tissue, respectively.

Evaluation of macroarray. The efficacy of the macroarray was tested for practical use to detect viruses from potato sam- 
ples in the field. We collected leaf samples from farmers' fields planted with landrace potato in May 2007. Some of the landrace potato cultivars were introduced before 1870 (20), and farmers continued to produce seed potato by themselves without tissue culture and virus testing. From 19 fields in Yamanashi, Nagano, and Shizuoka, 95 potato plants were collected and stored at $-80^{\circ} \mathrm{C}$. Of these, 11 samples were chosen using a random number generator and used for the macroarray test (Fig. 3). Results were compared with those from ELISA and RT-PCR using the same samples.

\section{RESULTS}

Primer design and cDNA amplification. Capture probe and target cDNA were evaluated by RT-PCR for the 12 viruses using discriminatory primer sets. Primer sets that amplified a single band at the expected position without nonspecific bands from the target virus-infected sample were selected, and those that produced nonspecific bands from plants infected with other viruses and healthy plants were excluded. For example, it was confirmed

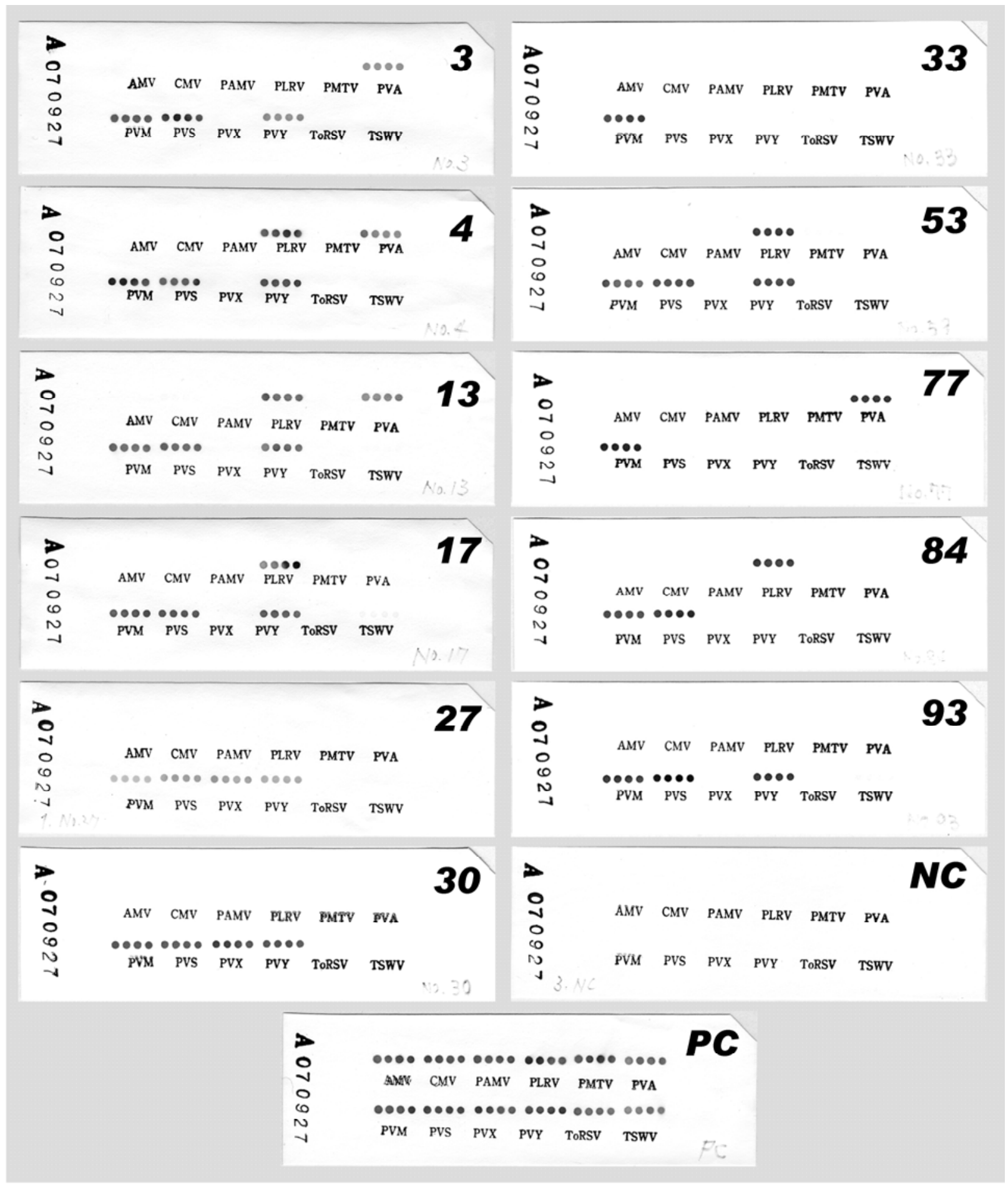

Fig. 2. Simultaneous macroarray detection of viruses present in single potato plants. Each virus name was printed below the quadruple spots, with the individual lot number on the left of the membrane. A healthy potato leaf was used as negative control (NC). Virus-specific complementary DNA (cDNA) was derived from each of single-infected samples of the 12 viruses, and biotin-labeled cDNAs were mixed and hybridized with a positive control (PC) membrane. $\mathrm{AMV}=$ Alfalfa mosaic virus, $\mathrm{CMV}=$ Cucumber mosaic virus, $\mathrm{PAMV}=$ Potato aucuba mosaic virus, $\mathrm{PLRV}=$ Potato leafroll virus, $\mathrm{PMTV}=$ Potato mop-top virus, $\mathrm{PVA}=$ Potato virus $A, \mathrm{PVM}=$ Potato virus $M, \mathrm{PVS}=$ Potato virus $S, \mathrm{PVX}=$ Potato virus $X, \mathrm{PVY}=$ Potato virus $Y$, ToRSV $=$ Tomato ringspot virus, TSWV = Tomato spotted wilt virus. 
that primers AMV2F and AMV1R amplified a 290-bp cDNA product only from an AMV-infected plant and not from any other plants infected with either of the 11 viruses or healthy plants (data not shown). In the same way, primer sets for CMV, PAMV, PLRV, PMTV, PVA, PVS, PVX, and PVY listed in Table 2 exclusively produced bands of their targets viruses (data not shown). Some of the initially designed primer sets for viruses such as ToRSV and TSWV produced single or multiple bands from healthy potato leaves by RT-PCR (data not shown). Consequently, primers were redesigned. For PVM strains (13), primer set PVM21R and PVM22F were selected from 22 sets of primers (data not shown). Amplified cDNAs for each virus ranging from 290 to $577 \mathrm{bp}$ were used as capture probes (Table 3 ).
Hybridization of target cDNA to probes on macroarray. The specificity of capture probes (Table 3 ) in the macroarray assay was confirmed by hybridization. For example, for AMV, when an AMV-infected plant was used as template, PCR was performed using primers AMV2F and AMV1R, and biotin-labeled cDNA was hybridized on a macroarray, clear signals were observed in the positions of capture probes for AMV, and there was no signal for other viruses in chemiluminescent detection (Fig. 1B). These results indicate that the AMV cDNA fragment did not cross-hybridize to other virus probes. Also, when healthy plants were used as template, PCR products using primers AMV2F and AMV1R produced no signal on the macroarray membrane (data not shown). Similarly, the primer sets for CMV, PAMV,

Table 3. Target regions and size of capture probes used in the macroarray

\begin{tabular}{lllc}
\hline Virus $^{\mathbf{a}}$ & \multicolumn{1}{c}{ Target region } & Sequence $^{\mathbf{b}}$ & Size (bp) $^{\mathbf{c}}$ \\
\hline AMV & Coat protein on RNA 3 & AB451173 & 290 \\
CMV & 2a Protein on RNA 2 & AB451174 & 434 \\
PAMV & 26-kDa protein & AB451175 & 366 \\
PLRV & Coat protein & AB451176 & 470 \\
PMTV & Read-through protein on RNA 2 & AB451177 & 471 \\
PVA & Coat protein and 3' untranslated region (UTR) & AB451178 & 460 \\
PVM & 23-kDa protein & AB451179 & 395 \\
PVS & Coat and 11-kDa proteins & AB451180 & 417 \\
PVX & Coat protein & AB451181 & 337 \\
PVY & Coat protein & AB451182 & 577 \\
ToRSV & Coat protein and 3' UTR on RNA 2 & AB451183 & 538 \\
TSWV & NSs protein on S RNA segment & AB451184 & 293 \\
\hline
\end{tabular}

${ }^{\mathrm{a}} \mathrm{AMV}=$ Alfalfa mosaic virus, $\mathrm{CMV}=$ Cucumber mosaic virus, $\mathrm{PAMV}=$ Potato aucuba mosaic virus, $\mathrm{PLRV}=$ Potato leafroll virus, $\mathrm{PMTV}=$ Potato mop-top virus, $\mathrm{PVA}=$ Potato virus $\mathrm{A}, \mathrm{PVM}=$ Potato virus $M, \mathrm{PVS}=$ Potato virus $S, \mathrm{PVX}=$ Potato virus $X, \mathrm{PVY}=$ Potato virus $Y$, ToRSV $=$ Tomato ring spot virus, $\mathrm{TSWV}=$ Tomato spotted wilt virus.

${ }^{\mathrm{b}} \mathrm{DDBJ} / \mathrm{EMBL} / \mathrm{GenBank}$ accession number.

${ }^{\mathrm{c}}$ Primer regions included.

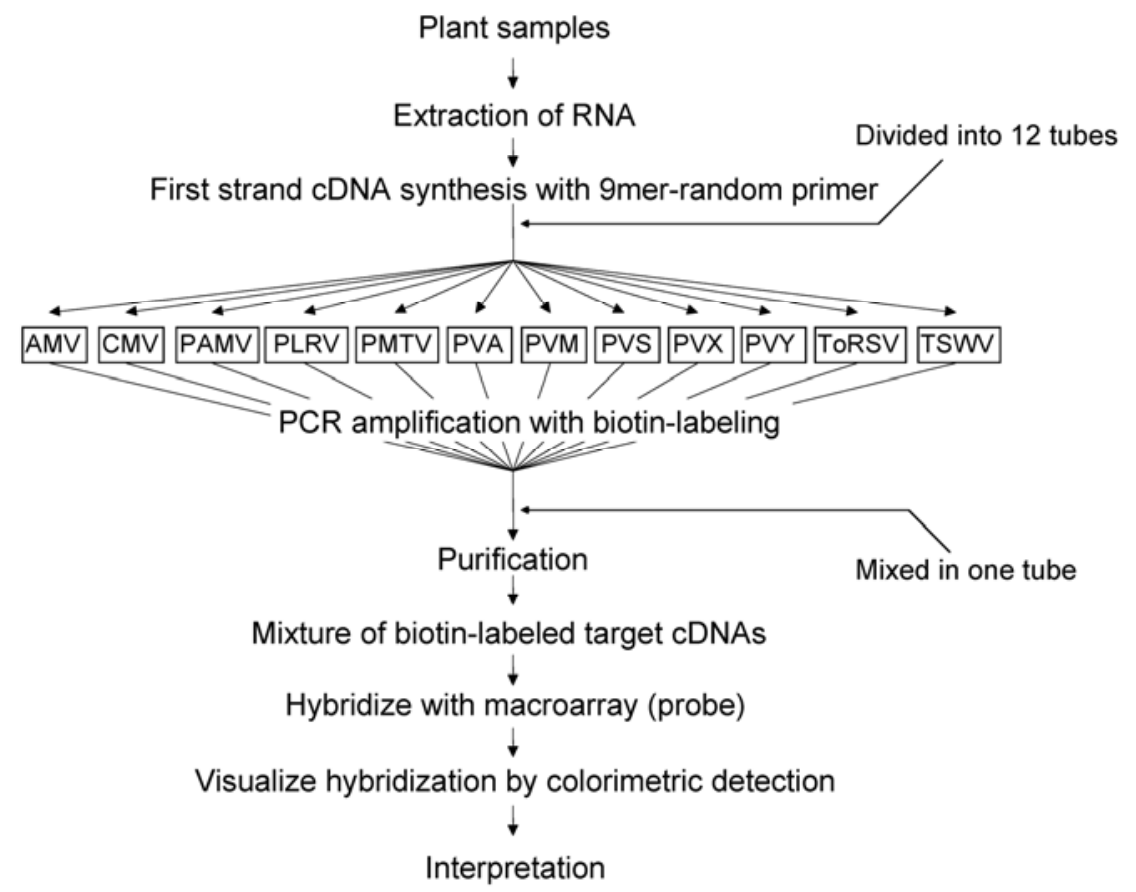

Fig. 3. Schematic outline of steps in macroarray detection of the 12 viruses for practical use. Washing steps not depicted.
PLRV, PMTV, PVA, PVM, PVS, PVX, PVY, ToRSV, and TSWV listed in Table 2 were confirmed in their hybridization specificity (Fig. 1B). Similar results were obtained by colorimetric detection (data not shown).

The specificity among genera or families was also determined. No crosshybridization was observed between viruses belonging to the same genera or families; in the case of AMV and CMV, both belonging to the family Bromoviridae, target cDNA amplified from an AMVinfected plant using primers AMV2F and AMV1R did not react to CMV probe, and vice versa. Also, cross hybridization was not detected between PAMV and PVX (the genus Potexvirus in the family Flexiviridae), PVM and PVS (the genus Carlavirus in the family Flexiviridae), or PVA and PVY (the genus Potyvirus in the family Potyviridae) (Fig. 1). However, in a preliminary study, nonspecific signals to other viruses were observed in the macroarray and were attributed to the labeling PCR using KOD Dash DNA polymerase (TOYOBO) (data not shown). Consequently, AmpliTaq Gold LD (Applied Biosystems) was selected to solve the problem from several thermostable DNA polymerase and used for the labeling PCR in this study, with a modification from the previous report (34).

Reactivity between $\mathrm{PVY}^{\mathrm{O}}$ and $\mathrm{PVY}^{\mathrm{N}}$ was confirmed using our laboratory collection. The probe for $\mathrm{PVY}^{\mathrm{O}}$ hybridized not only to the isolate of the same strain but also to an isolate belonging to $\mathrm{PVY}^{\mathrm{N}}$, although the probe had weaker hybridization signals to $\mathrm{PVY}^{\mathrm{N}}$ than to the homologous virus isolate (data not shown).

Sensitivity and evaluation of the macroarray. For all viruses except AMV, the sensitivity of the macroarray assay was higher than RT-PCR, and RT-PCR was more sensitive than ELISA (Table 4). For example, the threshold for PLRV detection was $160,0.0026$, and $0.0001 \mu \mathrm{g}$ of leaf tissue for ELISA, RT-PCR, and macroarray, respectively. The macroarray method was $5 \times 10^{2}$ (PVM) to $4 \times 10^{6}$ (PAMV) times more sensitive than ELISA, and 5 $(\mathrm{PVX})$ to $5 \times 10^{4}(\mathrm{CMV})$ times compared with RT-PCR (except AMV; Table 4). RTPCR detected a smaller amount of AMV than macroarray in two independent experiments. The lower sensitivity of macroarray for AMV may be ascribed to the secondary structure of the capture probe and the labeled cDNA, resulting in poor hybridization.

Our previous study revealed that only PVS, PVX, and PVY were occasionally detected from samples because farmers use certified seed potato lines for commercial cultivation in Japan (22). Therefore, we sought landrace potato cultivars which had not been cleaned up by tissue culture. One to five viruses were simultaneously detected from 11 Japanese landrace potato 
samples (Table 5), of which 6 were symptomless. Among the samples, macroarray detected one virus from Murasaki-imo (sample no. 33), two viruses from Misakubo-shiro (no. 77), and more than three viruses from other samples (Fig. 2). They were identified as PLRV, PVA, PVM, PVS, $\mathrm{PVX}$, and PVY and present in various combinations. AMV, CMV, PAMV, PMTV, ToRSV, and TSWV were not detected. Five viruses (PLRV, PVA, PVM, PVS, and PVY) were detected simultaneously from Fujinonegata (no. 4) and Ochiai-imo (no. 13) (Fig. 2). The macroarray signals obtained by colorimetric detection were distinct, and virus infection could be judged as positive or negative without difficulty.

Sensitivity was compared among ELISA, RT-PCR, and macroarray using the six viruses detected by macroarray to (Table 5). The three methods agreed well in their ability to detect the viruses, except PLRV and PVA. The macroarray was the only method detecting PLRV from Ochiaiimo (no. 13) and Misakubo-aka (no. 84). demonstrate the efficacy of the method

ELISA failed to find PLRV and PVA from Fujinonegata (no. 4) (Table 5).

\section{DISCUSSION}

There are prerequisites to the development of virus-detection methods that are acceptable for practical use, such as scaleup potential and convenience that does not require special expertise or clean, wellequipped laboratories. Sensitivity is also an important factor. Commonly used techniques for the detection of plant viruses include ELISA and RT-PCR or PCR $(14,23,37,38)$. RT-PCR has proven to be more sensitive than ELISA $(1,12,28)$. Macroarray assays for plant viruses have recently been developed $(1,2,33)$. Agindotan and Perry $(1,2)$ reported that sensitivity of their macroarray for 11 potato viruses and a viroid was comparable with that of DAS-ELISA but was lower than that for RT-PCR. Sugiyama et al. (33) reported that RT-PCR was more sensitive than macroarray for four lily viruses. Our cDNA macroarray method was generally more sensitive than RT-PCR and was always

Table 4. Comparison in sensitivity between enzyme-linked immunosorbent assay (ELISA), reversetranscription polymerase chain reaction (RT-PCR), and macroarray as estimated by dilution end-point (Dilution) and the amount of corresponding leave tissue (Estimate)

\begin{tabular}{|c|c|c|c|c|c|c|}
\hline \multirow[b]{2}{*}{ Virus $^{\mathrm{a}}$} & \multicolumn{2}{|c|}{ ELISA } & \multicolumn{2}{|c|}{ RT-PCR } & \multicolumn{2}{|c|}{ Macroarray } \\
\hline & Dilution & Estimate $(\mu \mathrm{g})$ & Dilution & Estimate $(\mu \mathrm{g})$ & Dilution & Estimate $(\mu \mathrm{g})$ \\
\hline AMV & $5^{-8}$ & 0.26 & $5^{-12}$ & 0.000004 & $5^{-10}$ & 0.0001 \\
\hline CMV & $5^{-8}$ & 0.26 & $5^{-7}$ & 0.0128 & $5^{-14}$ & 0.0000002 \\
\hline PAMV & $5^{-4}$ & 160.00 & $5^{-9}$ & 0.0005 & $5^{-12}$ & 0.000004 \\
\hline PLRV & $5^{-4}$ & 160.00 & $5^{-8}$ & 0.0026 & $5^{-10}$ & 0.0001 \\
\hline PMTV & $5^{-4}$ & 160.00 & $5^{-5}$ & 0.3200 & $5^{-9}$ & 0.0005 \\
\hline PVA & $5^{-4}$ & 160.00 & $5^{-4}$ & 1.6000 & $5^{-9}$ & 0.0005 \\
\hline PVM & $5^{-5}$ & 32.00 & $5^{-3}$ & 8.0000 & $5^{-6}$ & 0.0640 \\
\hline PVS & $5^{-5}$ & 32.00 & $5^{-6}$ & 0.0640 & $5^{-9}$ & 0.0005 \\
\hline PVX & $5^{-6}$ & 6.40 & $5^{-8}$ & 0.0026 & $5^{-9}$ & 0.0005 \\
\hline PVY & $5^{-4}$ & 160.00 & $5^{-7}$ & 0.0128 & $5^{-10}$ & 0.0001 \\
\hline ToRSV & $5^{-5}$ & 32.00 & $5^{-6}$ & 0.0640 & $5^{-10}$ & 0.0001 \\
\hline TSWV & $5^{-6}$ & 6.40 & $5^{-7}$ & 0.0128 & $5^{-10}$ & 0.0001 \\
\hline
\end{tabular}

${ }^{\mathrm{a}} \mathrm{AMV}=$ Alfalfa mosaic virus, $\mathrm{CMV}=$ Cucumber mosaic virus, $\mathrm{PAMV}=$ Potato aucuba mosaic virus, $\mathrm{PLRV}=$ Potato leafroll virus, $\mathrm{PMTV}=$ Potato mop-top virus, $\mathrm{PVA}=$ Potato virus $\mathrm{A}, \mathrm{PVM}=$ Potato virus $M, \mathrm{PVS}=$ Potato virus $S, \mathrm{PVX}=$ Potato virus $X, \mathrm{PVY}=$ Potato virus $Y$, ToRSV $=$ Tomato ring spot virus, TSWV = Tomato spotted wilt virus. more sensitive than ELISA. Individual PCR using primers specific to each virus amplified target viruses exclusively and enhanced the sensitivity of the macroarray.

Simultaneous detection of plant pathogens using macroarray has been reported in many articles $(1,2,10,33,36,39,40)$. For simultaneous detection of plant viruses using macroarray, cross- or nonspecifichybridizations complicated interpretation, hindering practical use. Agindotan and Perry $(1,2)$ used universal primers to amplify any RNAs of potato pathogens. In addition, to reduce the risk of overlooking potential pathogens, they included additional sets of oligonucleotide capture probes. Their methods incited nonspecific hybridization, even though it detected a wider range of pathogens. In our macroarray detection, a single capture probe was selected for each virus and blotted onto the macroarray. In addition, 12 PCR reactions with biotin-labeling were performed using one primer pair for each of the 12 virus, and AmpliTaq Gold LD (Applied Biosystems) was selected for PCR. Because of those modifications, no cross-hybridization was observed in our examination. This made interpretation simpler than other macroarray assays (2). In this report, we demonstrated that five viruses were simultaneously detected by macroarray. This is the first example of simultaneous detection using macroarray from field samples.

Intraspecies variation has been reported to exist in some of the viruses tested in this study $(7,11)$. Strains $\mathrm{PVY}^{\mathrm{O}}$ and $\mathrm{PVY}^{\mathrm{N}}$ were reported to be distinguishable serologically $(7,8)$. We could detect both strains of PVY using the macroarray, although the signal for $\mathrm{PVY}^{\mathrm{N}}$ was relatively weak. Genetic diversity within Japanese isolates of PVM was reported by Hataya and Maoka (13). Following their results, we designed 22 sets of primers from all regions of genomic sequence of PVM (data not shown) and, of them, only PVM21R and PVM22F, which amplified

Table 5. Detection of potato viruses from field samples by enzyme-linked immunosorbent assay (E), reverse-transcription polymerase chain reaction (R), and macroarray $(\mathrm{M})$

\begin{tabular}{|c|c|c|c|c|c|c|c|c|c|c|c|c|c|c|c|c|c|c|c|c|}
\hline \multirow[b]{3}{*}{ No. ${ }^{\text {b }}$} & \multirow[b]{3}{*}{ Cultivar } & \multirow[b]{3}{*}{ Symp. $^{\mathrm{c}}$} & \multicolumn{18}{|c|}{ Virus $^{\mathrm{a}}$} \\
\hline & & & \multicolumn{3}{|c|}{ PLRV } & \multicolumn{3}{|c|}{ PVA } & \multicolumn{3}{|c|}{ PVM } & \multicolumn{3}{|c|}{ PVS } & \multicolumn{3}{|c|}{ PVX } & \multicolumn{3}{|c|}{ PVY } \\
\hline & & & $\mathbf{E}$ & $\mathbf{R}$ & M & $\mathbf{E}$ & $\mathbf{R}$ & M & $\mathbf{E}$ & $\mathbf{R}$ & M & $\mathbf{E}$ & $\mathbf{R}$ & M & $\mathbf{E}$ & $\mathbf{R}$ & M & $\mathbf{E}$ & $\mathbf{R}$ & M \\
\hline 3 & Fujinonegata & $\mathrm{sl}$ & - & - & - & + & + & + & + & + & + & + & + & + & - & - & - & + & + & + \\
\hline 4 & Fujinonegata & $\mathrm{m}$ & - & + & + & - & + & + & + & + & + & + & + & + & - & - & - & + & + & + \\
\hline 13 & Ochiai-imo & $\mathrm{m}$ & - & - & + & + & + & + & + & + & + & + & + & + & - & - & - & + & + & + \\
\hline 17 & Seinaiji-shiro & $\mathrm{sl}$ & + & + & + & - & - & - & + & + & + & + & + & + & - & - & - & + & + & + \\
\hline 27 & Hiratani-imo & sl & - & - & - & - & - & - & + & + & + & + & + & + & + & + & + & + & + & + \\
\hline 30 & Hiratani-imo & $\mathrm{sl}$ & - & - & - & - & - & - & + & + & + & + & + & + & + & + & + & + & + & + \\
\hline 33 & Murasaki-imo & sl & - & - & - & - & - & - & + & + & + & - & - & - & - & - & - & - & - & - \\
\hline 59 & Shimoguri-aka & $\mathrm{m}$ & + & + & + & - & - & - & + & + & + & + & + & + & - & - & - & + & + & + \\
\hline 77 & Misakubo-shiro & $\mathrm{m}$ & - & - & - & + & + & + & + & + & + & - & - & - & - & - & - & - & - & - \\
\hline 84 & Misakubo-aka & $\mathrm{m}$ & - & - & + & - & - & - & + & + & + & + & + & + & - & - & - & - & - & - \\
\hline 93 & Zairai-murasaki & $\mathrm{sl}$ & - & - & - & - & - & - & + & + & + & + & + & + & - & - & - & + & + & + \\
\hline
\end{tabular}

a Viruses detectable by any of the three methods are listed. PLRV $=$ Potato leafroll virus, $\mathrm{PVA}=$ Potato virus $A, \mathrm{PVM}=$ Potato virus $M$, $\mathrm{PVS}=$ Potato virus $S, \mathrm{PVX}=$ Potato virus $X, \mathrm{PVY}=$ Potato virus $Y$.

${ }^{\mathrm{b}}$ Sample number.

c Abbreviations for symptoms: $\mathrm{sl}=$ symptomless, $\mathrm{m}=$ weak mottling, $-=$ reaction negative, and $+=$ reaction positive. 
the 23-kDa protein region, detected all isolates tested by RT-PCR. Selection of a suitable primer set and probe was the key to obtaining strong signals of PVM in the field trial (Fig. 2). A similar difficulty in PVM detection was reported by Agindotan and Perry (2).

There are several limitations of the macroarray technique. One is common to PCR-based techniques, including macroarray. Any virus variant with a genome sequence mutation may not be amplified or detected. The risk of overlooking potential pathogens by our macroarray may be higher than the previous one (2). Another limitation is scale-up potential. Although macroarray is not as effective as RT-PCR or ELISA in terms of experimental scaleup, our macroarray is equivalent to other array-based techniques $(2,33)$. Macroarray is not designed to examine a large number of samples but is suitable for the simultaneous detection of many different viruses.

Our macroarray is also improved in convenience. For certification and field survey, the macroarray method should be simple and provide clear-cut results. The macroarray method consists of common techniques such as RT-PCR and hybridization. Colorimetric detection requires no expensive equipment (e.g., imaging system for fluorescence or chemiluminescence in micro- or macroarray detections) and enables visual interpretation. Virus names printed on macroarray membranes helped prompt visual interpretation. In addition, the cDNA macroarray is commercially available (LAB Company, Sapporo, Japan). These advantages should accelerate ubiquitous distribution of the technique.

In conclusion, we established the technique for sensitive and simultaneous detection of the 12 viruses from potato. The efficacy of the method for practical use was proved by the test with field samples. This technique has a potential for practical use such as breeding, quarantine, foundation of seed potato production, and field survey as well as application to other plant viruses.

\section{ACKNOWLEDGMENTS}

We thank H. Fuwa and K. Matsuo for providing virus isolates; Yamanashi Prefectural Agricultural Technology Center, Tabayama Village Office of Yamanashi Prefecture, Seinaiji Village Office of Nagano Prefecture, Shimoina Agriculture Extension Center of Nagano Prefecture, M. Ohi, and K. Noguchi for their support of field study; K. Okuguchi, C. Mikami, and T. Yanagidate for their technical support; and Y. Hayano, N. Matsumoto, M. Mori, K. Hosaka, and C. Masuta for their helpful suggestions. This research was grant-aided by the Agriculture, Forestry and Fisheries Research Council, the Ministry of Agriculture, Forestry and Fisheries, Japan (no. 1722).

\section{LITERATURE CITED}

1. Agindotan, B., and Perry, K. L. 2007. Macroarray detection of plant RNA viruses using randomly primed and amplified complementary DNAs from infected plants. Phytopathology 97:119-127.

2. Agindotan, B., and Perry, K. L. 2008. Macroarray detection of eleven potato- infecting viruses and Potato spindle tuber viroid. Plant Dis. 92:730-740.

3. Akimoto, Y., Matsuzawa, K., and Kurihara, M. 1958. On the potato virus S. Ann. Phytopathol. Soc. Jpn. 23:42. (in Japanese)

4. Altschul, S.F., Gish, W., Miller, W., Myers, E. W., and Lipman, D. J. 1990. Basic local alignment search tool. J. Mol. Biol. 215:403-410.

5. Asuyama, H., and Hirai, T. 1949. On the crinkle-mosaic viruses of potato in Japan. Ann. Phytopathol. Soc. Jpn. 13:29-32. (In Japanese)

6. Benson, D. A., Karsch-Mizrachi, I., Lipman, D. J., Ostell, J., and Wheeler, D. L. 2008. GenBank. Nucleic Acids Res. 36:D25-D30.

7. de Bokx, J. A., and Huttinga, H. 1981. Potato virus Y. Descriptions of Plant Viruses, No. 242 (No. 37 revised), CMI/AAB, Surrey, England.

8. Chikh Ali, M., Maoka, T., and Natsuaki, K. T. 2007. A point mutation changes the serotype of a Potato virus $Y$ isolate; genomic determination of the serotype of PVY strains. Virus Genes 35:359-367.

9. Clark, M. F., and Adams, A. N. 1977. Characteristic of the microplate method of enzymelinked immunosorbent assay for detection of plant viruses. J. Gen. Virol. 34:475-483.

10. Fessehaie, A., De Boer, S. H., and Lévesque, C. A. 2003. An oligonucleotide array for the identification and differentiation of bacteria pathogenic on potato. Phytopathology 93:262269.

11. Francki, R. I. B., Mossop, D. W., and Hatta, T. 1979. Cucumber mosaic virus. Descriptions of Plant Viruses, No. 213, CMI/AAB, Surrey, England.

12. García, M. L., Sánchez De La Torre, M. E., Dal Bo, E., Djelouah, K., Rouag, N., Luisoni, E., Milne, R. G., and Grau, O. 1997. Detection of citrus psorosis-ringspot virus using RT-PCR and DAS-ELISA. Plant Pathol. 46:830-836.

13. Hataya, T., and Maoka, T. 2008. Genetic diversity and serological differences of potato virus M isolates. Ann. Phytopathol. Soc. Jpn. 74:234. (In Japanese)

14. Henson, J. M., and French, R. 1993. The Polymerase chain reaction and plant disease diagnosis. Annu. Rev. Phytopathol. 31:81-109.

15. Hirai, T., Yasumi, T., and Kato, H. 1955. Studies on the virus diseases of potatoes. III. Fgroup viruses of the potato. Bull. Tohoku Natl. Agric. Exp. Stn. 4:53-63. (In Japanese with English abstract)

16. Horio, H., Yano, I., and Esumi, K. 1969. Potato virus $M$ found in Japan. Ann. Phytopathol. Soc. Jpn. 35:47-54. (In Japanese with English abstract)

17. Imoto, M., Iwaki, M., Tochihara, H., Nakamura, K., and Hanada, K. 1986. The occurrence of potato mop top virus in Japan and some of its properties. Ann. Phytopathol. Soc. Jpn. 52:752-757. (In Japanese with English abstract)

18. Kasai, M. 1921. Observations and experiments on the leafroll disease of the Irish-potato in Japan. Ber. Ohara Inst. Landwirtsch. Forsch. 2:44-77.

19. Komuro, Y., Kawada, T., Hirano, Y., and Muroki, M. 1964. Occurrence of potato calico disease, caused by alfalfa mosaic virus, in Japan. Ann. Phytopathol. Soc. Jpn. 29:199-205. (In Japanese with English abstract)

20. Kunitomo, Y., and Kubota, K. 2002. Collection and investigation of crop and vegetables landraces in Yamanashi prefecture, 1999-2001. Bull. Yamanashi Agric. Res. Cent. 11:71-76. (In Japanese)

21. Maoka, T., and Hataya, T. 2005. The complete nucleotide sequence and biotype variability of Papaya leaf distortion mosaic virus. Phytopathology 95:128-135.

22. Maoka, T., Yanagidate, T., Maruta Y., and Hataya, T. 2006. Survey of twelve viruses of potatoes collected from Hokkaido, Kanagawa, Nagano, Okayama, Nagasaki, Kagoshima and
Okinawa prefectures. Ann. Phytopathol. Soc. Jpn. 72:85-86. (In Japanese)

23. Martin, R. R., James, D., and Levesque, C. A 2000. Impacts of molecular diagnostic technologies on plant disease management. Annu. Rev. Phytopathol. 38:207-239.

24. Matsunami, M., and Suetsugu, T. 1970. Occurrence of potato virus A in Japan. Res. Bull. Plant Prot. Serv. Jpn. 8:13-20. (In Japanese with English abstract.)

25. Matsunami, M., Suetsugu, T., and Motoshima S. 1972. Detection of cucumber mosaic virus from potato in Japan. Res. Bull. Plant Prot. Serv. Jpn. 10:17-22. (In Japanese with English abstract.)

26. Matsuo, K., Uchikawa, K., Okuda, M., and Iwanami, T. 2003. Necrosis disease of potato plant caused by Tomato spotted wilt virus. Ann. Phytopathol. Soc. Jpn. 69:342. (In Japanese)

27. Nie, X., and Singh, R. P. 2001. A novel usage of random primers for multiplex RT-PCR detection of virus and viroid in aphids, leaves and tubers. J. Virol. Methods 91:37-49.

28. Sánchez-Navarro, J. A., Aparicio, F., Rowhani, A., and Pallas, V. 1998. Comparative analysis of ELISA, nonradioactive molecular hybridization and PCR for the detection of prunus necrotic ringspot virus in herbaceous and Prunus hosts. Plant Pathol. 47:780-786.

29. Sato, M., Goto, T., and Honda, Y. 2000. Tomato ringspot virus isolated from potato and petunia plants. Ann. Rep. Plant Prot. North Japan 51:93-97. (In Japanese with English abstract)

30. Sato, M., Goto, T., and Honda, Y. 2001. $C u$ cumber mosaic virus in potato and its transmission through tubers. Ann. Rep. Plant Prot. North Japan 52:34-37. (In Japanese with English abstract)

31. Sato, M., Hataya, T., and Iwasaki, M. 2000. Detection of four viruses in dormant potato tubers by RT-PCR. Ann. Rep. Plant Prot. North Japan 51:87-92. (In Japanese with English abstract)

32. Slack, S. A., and German, T. L. 2001. Disease caused by viruses and viroids. Pages 57-62 in Compendium of Potato Diseases, 2nd ed. W. R. Stevenson, R. Loria, G. D. Franc, and D. P. Weingartner, eds. American Phytopathology Society, St. Paul, MN

33. Sugiyama, S., Masuta, C., Sekiguchi, H Uehara, T., Shimura, H., and Maruta, Y. 2008 A simple, sensitive, specific detection of mixed infection of multiple plant viruses using macroarray and microtube hybridization. J. Virol. Methods 153:241-244.

34. Sugiyama, S., Yamamoto, K., Nishimura, N., Nakagawa, M., Maruta, Y., and Ando, J. 2007 Adequate design of customized cDNA macroarray for convenient multiple gene expression analysis. J. Biosci. Bioeng. 103:74 81.

35. Tanaka, I., Murayama, D., and Oshima, N. 1956. Studies on the X-mosaic disease of potato. Hokkaido Natl. Agric. Exp. Stn. Rep. 49:1-76. (In Japanese)

36. Uehara, T., Kushida, A., and Momota, Y. 1999. Rapid and sensitive identification of Pratylenchus spp. using reverse dot blot hybridization. Nematology 5:549-555.

37. Vincelli, P., and Tisserat, N. 2008. Nucleic acid-based pathogen detection in applied plant pathology. Plant Dis. 92:660-669.

38. Webster, C. G., Wylie, S. J., and Jones, M. G. K. 2004. Diagnosis of plant viral pathogens Curr. Sci. 86:1604-1607.

39. Zhang, N., Geiser, D. M., and Smart, C. D. 2007. Macroarray detection of solanaceous plant pathogens in the Fusarium solani species complex. Plant Dis. 91:1612-1620.

40. Zhang, N., McCarthy, M. L., and Smart, C. D. 2008. A macroarray system for the detection of fungal and oomycete pathogens of solanaceous crops. Plant Dis. 92:953-960. 